\title{
IJBF IS ISLAMIC BANKING CAPABLE OF MEETING CORPORATE SOCIAL RESPONSIBILITY?
}

\author{
Sarath Delpachitra \\ Flinders University, Australia
}

\begin{abstract}
This paper provides an overview of the Islamic banking system and its product ranges, and examines their ability to meet Corporate Social Responsibility obligations while maintaining efficiency and managing risk. The growing literature on Islamic banking products, including their derivatives indicates that Islamic banking is popular worldwide and has global attention. Similarly, the diversity of banking options is growing in Middle Eastern countries with some banks offering separate windows for conventional and Islamic banking options to customers. Due to the unique nature of Islamic banking, which is constrained not only by the standard operating regulations of the respective countries, but also by Islamic law, the Sharī'ah, there are significant differences in the philosophy behind its finance transactions, the nature of transactions, goals and the obligations between the two types of institutions. Whether these differences lead to changes in risk preferences, lending decision-making processes, and the ultimate efficiency of operations are some of the key empirical questions yet to be fully answered. The paper introduces a theory based on classical utility theory, and then extends it to show its relevance to Islamic banking. In particular this paper shows that Islamic banking may not only improve operating performance, but also increase profitability for all parties concerned.
\end{abstract}

Key words: Islamic banking; corporate social responsibility; sharilah JEL Classification: G 34

\section{Introduction}

Islamic banking is growing fast, but the increase in the size of Islamic banking IB is questionable (Abdallah \& Delpachitra, 2008). Over the past decade, Islamic banking has substantially broadened its publicity worldwide by taking overall leadership in many Islamic communities. For instance, total Islamic assets worldwide expanded from US\$137 billion in 1996 to approximately US $\$ 900$ billion in 2010, a linear annual growth rate of 40\%: in 2013, the size is reported to be US $\$ 1,700$ billion. Despite this progress, the total volume of international 
transactions is still very small, as would be the case of a niche banking with just about 50 year history. However, the growing credibility of the Islamic principledriven, interest-free financial intermediary based on either fee-based or profitshared pricing of financial products in the international financial markets and the positive evidence of its adaptations worldwide in particular, should receive the attention of regulators, researchers and investors. The growth of credibility is considered the driving force behind creating a viable alternative, at least where the customers demand such products as being more in line with human ethics, to the conventional banking system.

On closer inspection, both the conventional and IB systems have similarities and differences. Both systems focus on the classical wisdom of shareholder or corporate wealth maximization. However, Islamic banking attempts to achieve these objectives through a set of Islamic laws (Sharī'ah) that basically prevents managing the financial institution (and the market) through the margins of interest income and interest cost. Basically it promotes principalagent relationships in financial transactions in which profits or returns reflecting pure opportunity costs are divided among stakeholders fairly and equitably. In that sense this paper assumes that the Islamic banks should play a role similar to that of a venture capitalist (VC).

On the other hand, as Sairelly (2007, p 279) states, the ethical credentials of Islamic financial institutions make them attractive to not only Muslims, but also to a wide spectrum of ethically-conscious consumers who desire a socially just financial system. By extending this proposition to the basic role of the financial system, both saving and borrowing units expect that the Islamic financial intermediation ensures that returns are distributed (among investors, entrepreneurs and other stakeholders) in a socially responsible manner. Based on the guidance from the Holy Text $3 / 4$ the Qurãn $3 / 4$ the rules for Islamic economic and financial practices, for individual entrepreneurs and investors, and institutional investors should not only be concerned with what kind of business transactions they should be involved with, but also with how such businesses should be funded, because Islamic transactions should not only be Sharīah-compliant (halāl) but should also be free of exploitation of the weak, free of interest (riba $\bar{a})$ and exclude prohibited transactions such as those involving gharar, etc.

Sairally (2007) pinpoints a number of criticisms of the practice of Islamic finance. These criticisms cover the heavy bias towards 'mark-up financing' contracts (murābahah) in profit-and-loss-sharing arrangements, and 'trustee finance' contracts (murābahah): it is also claimed that Islamic banking is mirroring the practices of conventional banking. These criticisms were further supported by Abdallah and Delpachitra (2008) suggesting that IB uses identical strategies in risk preference and risk profiling to those of conventional banking. Despite these criticisms, it can be shown that IB provides the best solution to the issue of ethically and socially responsible banking. In this paper, we try to establish that. Essentially this paper shows that if the principles of Sharīah are applied, IB participation in the financial system can improve the operating performance of firms, and as IB shares a higher percentage of profits with 
entrepreneurs, the investee firms' operating performance is improved. This provides more incentives for IB to act in a socially responsible manner.

This paper is organized as follows. Section 2 provides a brief overview of IB transactions relevant to this paper. Section 3 introduces the concept of Corporate Social Responsibility (CSR) and its relevance to IB. Section 4 provides a detailed description of the quantitative framework for classical interpretation of principal-agent relationships using utility functions. The last section summarizes and concludes this paper.

\section{Islamic Banking Transactions}

Islamic banks are required to comply with Islamic ethics and in order to do so every Islamic bank must have a board of Sharī‘ah scholars, or a Sharīah Supervisory Board (SSB) to review the juristic correctness of the bank's transactions (Archer \& Karim, 2002). Furthermore, as Sarker (1999) points out, the primary objectives of Islamic finance cover broad-based economic wellbeing, social and economic justice, and equitable distribution of income and wealth. In order to achieve these objectives, different Islamic financial instruments and their derivative products have been introduced by Islamic institutions. For instance, mark-up pricing (murābaḩah), ultimately creates instruments to finance economic transactions. Consequently, murābaḥah is 'a common instrument used for short-term financing based on the conventional concepts of purchase finance' (Dhumale \& Sapcanin, 2003, p. 34). The seller reports to the buyer the cost of acquiring or producing a good, and then a profit margin is negotiated between the two parties. 'Typical asset-backed security in the conventional system is a claim against a pool of assets; Islamic instruments are claims against individual assets' (Anwar, 2003, p. 63). A distinct feature of such financial securities is that they resemble conventional debt securities characterised by a predetermined pay-off, with the difference being that Islamic instruments and their derivatives are collateralized against a real asset or economic activity.

In contrast in 'trustee finance' (murābahah) contracts, a principal with capital can develop a partnership with an agent (or entrepreneur) who has expertise in deploying capital in real economic activities with an agreement to share the profits (Hasan, 2002). Losses are borne by the capital owner only, as the other party does not hold any capital. Further, though the capital owner is exposed to loss or risk, he is not entitled to participate in the management of the funds; this is exclusively left to the other partner. However this form of funding is no more than at best $25 \%$ of the total funding by banks given its huge still unresolvable asymmetric information problem.

Furthermore, in 'equity participation' (mushärakah), which is a sharelike arrangement, the capital owner enters into a partnership by contributing equity together with the entrepreneur(s). Their contributions need not be equal, and contributions may be in the form of physical or monetary assets. Intangible capital, such as labour, management, skill and goodwill can form part of the 
capital (Lewis \& Algaoud, 2001). Profits can be shared in any pre-agreed ratio, but losses must be borne strictly in proportion to equity participation. This contract is suitable for long-term project financing. Some scholars consider this to be the purest form of Islamic finance since according to them it is closest to the spirit of Sharī'ah, does not have exploitative provisions, and is a fairly equal contract for both parties. Mushārakah financing is closer to a traditional equity stake with rights of control.

In between these three commonly used instruments and their derivatives of mushārakah, murābahah and murābahah, there are other collateralized securities, such as ijārah (similar to a lease or a lease purchase arrangement), kafälah and amānah contracts. These instruments can be classified exclusively into transactional and intermediation contracts in an Islamic financial system. Transactional contracts govern retail sector transactions that include exchange, trade and other financing activities. The intermediation contracts not only govern indirect financial instruments, but also facilitate the efficiency and transparency of the execution of transactional contracts (El-Hawary, Grais \& Iqbal, 2004).

In each of these cases, IB ensures that transactions comply with not only prudential standards, but also with the rules of Sharī'ah, to ensure a fair deal for both contracting parties unlike in interest-only contract, which is onesided. From a historical point of view profit-and-risk-shared contracting was the dominant form of funding economic activities until the birth of fractional banking some 250 years ago. The old practice was replaced slowly with interestonly no-risk-sharing lending as a one-sided cheaper form of lending while banks used deposits to create more money on each dollar of deposits to make more interest-based no-risk-shared lending.

\section{CSR and Islamic Banking}

Islamic finance, given its ethical characteristics some of which has been highlighted in the previous section, is often associated with ethical investment, which itself is linked to socially responsible investing. The restrictions on investment choices such as prohibition of investment in armaments sector, pornography, etc. are important examples. The concepts in question are similar. An Islamic bank provides financial services according to religious precepts in the same way as ethical finance also focuses on moral values (Guyot, 2009).

At a contemporary time when capitalism is growing blindly as evidenced by financial scandals such as those of Enron and later the Maddof scam, the notion of ethics has jumped for attention and companies are reflecting more and more on ethics. Many organizations are now displaying their ethical and moral concerns in the media. The aim is to reassure stakeholders (i.e., any party or person who maintains links, or indirectly are linked to a company such as suppliers, customers, shareholders, etc.), that all their interests matter to the company, not just the profits. This paper considers ethics as an integral part of 
CSR. Howard R. Bowen is often seen as the founder of CSR after publication of his book titled Social Responsibilities of the Businessman (Bowen, 1953) in which he attempts to convince business leaders to avoid regulatory constraints that reduce their freedom of action. According to the liberal vision of North America, 'businessmen should therefore incorporate the public interest in their decisions' (Acquires \& Aggeri, 2008). Since this contribution from Bowen, the definition of CSR was gradually reformulated. That facilitated further research on CSR. According to Carroll (1979), CSR refers to 'the expectations of society towards the company in the economic, legal, ethical and discretionary plans'.

In this context of CSR, socially responsible investment (SRI) has been developed as a form of ethical finance. We talk about SRI when 'the primary purpose of the investment is profitable but additional constraints are imposed' (Winant, 2008). However, we should be cautious about the conceptual vagueness that still exists between various forms of investment despite avowed commitment to CSR. Unless each product is designed with CSR concerns and there is a body of regulations to certify that as a fact in the design of financial products, statement such as what we quoted holds no binding commitment. Socially responsible investments are selected on 'ethical characteristics, assessed by the rating agencies' (Winant, 2008) Thus, Islamic finance can be considered a form of socially responsible finance in that it chooses legal and lawful financial assets, but both have their difference in religious character.

\section{Islamic Banking: A Classical View}

In general business, entities are growing larger and more complicated than ever with an increasing number of business models. In many cases ownership and management are separated. As a result, the agents or the management tend to put their personal interests as the top priority (Lin, 2004). They initiate decisions to maximize their benefits, instead of the principals' benefits, let alone stakeholders' benefits. Due to the principals' limited capabilities to process information, agency issues are created.

As noted before, IB differs from conventional financial institutions and investors because IB not only provides funds and services to the investee firms, but also supervises the investee firms based upon their investment plans and their compliance to a set of religiously-oriented restriction. The IBs' ultimate goal is to ensure that the investee firms make sound investment and development decisions under strict supervision, thereby not only improving the investee firms' operating performance and values based upon their experience as well as their knowledge and technical capabilities, while ensuring that they comply with the principles of Sharī'ah, which aims to advance human welfare in ethics-based financial transactions. In many cases information asymmetry becomes a serious issue due to high risk and the limited knowledge of the technical processes. Therefore, it is an important task to analyze models based upon the agency theory. 
Based upon the classical model inference by Holmstrom's (1979) assumption regarding the agent's utility function, it is assumed that both principal and agents are fully aware that they both rationally pursue the maximization of utility. Therefore, the agents strive to increase the firms' outputs; and then principals and agents distribute the outputs according to the compensation system. In other words, agents work hard in order to improve the firms' value, thereby increasing their wealth, and thus the agents' utility is increased. However, the firms' outputs are determined in accordance with the agents' contributions and other reasons beyond the agents' control. The factors beyond the agents' control are called uncontrollable risk. As far as agency relationship is concerned, wealth is the only element that determines the agents' utility function. However, the agents' utility functions are determined according to their wealth and their contributions to the investee firm. Therefore, contributions result in a negative utility and the negative utility increases as contributions increase.

Agency relationship research often places equal emphasis on both supervision and incentive plans (Shleifer \& Vishny, 1997). However, more recent research shows that supervision and incentive supplement each other (Lin, 2004). IB provides incentive compensation to inspire the entrepreneurs to improve the investee firms' operating performance. The entrepreneurs receive bonuses and dividends, in addition to their fixed salaries. The IBs design the incentive mechanism to ensure that the clients' interests are satisfied through the entrepreneurs' decisions and behavior. The control mechanism is designed to minimize the agency-related issues and harmonize the relationships between principals and agents. IBs differ from conventional fund providers because they not only provide funds, but are also required to take part in the administration or decision-making processes of the investee firms in order to ensure proper compliance with the principles of Islam. If the conventional Agency Theory by Amit, Glosten and Muller (1990) is interpreted in the Islamic sense, IBs supervise the agents as long as information asymmetry exists between IBs and investee firms. Holmstrom (1979) states that agents' compensation serves as an incentive mechanism. However, the supervision mechanism was not included in the model. A firm's production would also be affected by supervision. Therefore, following Holmstrom (1979) the principal's participation is included as the supervision mechanism for agents in the model used in this paper.

Holmstrom (1979) incorporates the neo-classical utility theory into his model and assumed that human beings pursue maximization of personal interests. The Basic Model between Principals and Agents of Holmstrom stresses the value of information. But it overlooks the contributions made by technology and knowledge to production. The utility function is a useful model to describe the behavior of principal and agents. IB behavior can be analyzed in accordance with agency theory. In considering model specification and the robustness of the inferences, this paper assumes that an agency relationship exists between Islamic investors (or IB) and entrepreneurs (investee firms). It thus attempts to solve the limitations of the Basic Model between Principals and Agents to create a well-defined model of the agency relationship between IB and investee firms. 
Agency theory is incorporated into the Islamic banking model with emphasis on the Saving Units (SU) (the investors) contributions to, and influence on the Borrowing Units (BU) (the entrepreneurs) when information asymmetry exists between the SU and BU. Islamic investors and entrepreneurs are assumed to be risk-averters as in standard theory and, as far as the agency relationship is concerned, neither party may disturb the other party. This is further complemented by their Islamic faith, that is, the relationships are Sharī ah-compliant as to be continually supervised. Therefore, the SUs and BUs attempt to maximize their personal utility and abide by the contracts at the same time.

Entrepreneurs act as agents for Islamic investors and are therefore required to work in the best interests of the investors. In the light of information asymmetry, Islamic investors need to launch incentive plans to inspire the entrepreneurs to work for the best interest of the Islamic investors, thereby minimizing the conflicts of interest between the entrepreneurs and Islamic investors. In other words, the investee firms' operating performance changes the entrepreneurs' compensation positively, thus the Islamic investors and entrepreneurs share a common interest.

Operating performance determines the profit level. In the case of Islamic finance, an incentive plan alone cannot solve the conflicts of interest resulting from attitudes towards risk. In this case, the supervision mechanism can reduce conflicts of interest and check for any deviation from Islamic principles. As stated earlier, IBs provide not only funds, but also extra services to the investee firms commensurate with Sharī ah. Therefore, a key decision variable $3 / 4 \mathrm{IB}$ participation $3 / 4$ is included in the model to determine the contributions made by IBs to investee firms. An information asymmetry between the Islamic investors and entrepreneurs is assumed; and IB participation serves as a supervisory mechanism.As far as the agency relationship between an IB and entrepreneurs is concerned, it is assumed that the wealth possessed by the IB, or the difference between the firm's profits and the entrepreneur's income, determines the IB's utility function. The entrepreneurs' utility function is determined by the firms' profits and the investee firms' operational achievement. Further, it is assumed that operational advancement creates negative utility for the entrepreneurs. This paper adopts the theoretical framework of Holmstrom's (1979) to explain its relevance to IB and financial transactions. Holstrom's model is extended to include the critical contributions made by firms as well as the principals' contributions to operating performance. The model makes the following assumptions:

- Firms increase their productivity through operational advancement. Therefore, the investee firms' operating capabilities determine the IB's outputs. Let $\gamma \in A \subseteq R \quad$ be the investee firm's operating capability, $A$ be the set of relevant technologies and $R$ be the set of real numbers. The investee firms are free to choose either to request IBs or research institutes for technological transfer or cultivate specialists to upgrade their firm's operational capabilities. Facing information asymmetry, 
entrepreneurs are likely to determine whether to initiate the decisions related to operational improvement based on their personal interests. Thus, their decisions affect the firms' profits;

- $\quad$ Let $q$ represent the IB's profits. The profits are determined in accordance with a number of factors beyond the entrepreneurs' control, in addition to $\gamma$. These factors are represented by a random variable $\theta$; knowns a random state of nature. It is assumed to represent the external environmental factors affecting the IB's profits. It is assumed that the entrepreneurs face $\theta$ after $\gamma$ is selected. In other words, the profits of the IB $q$ are determined by the investee firms' operational capabilities $\gamma$, together with the random variable $\theta$; that is. It is assumed that the entrepreneurs only adopt technologies that increase profits. Further, it is assumed that the marginal profits created via the investee firms' operational capabilities decrease. Thus $q=q(\gamma, \theta)$ is continuously differentiable up to the second order partial derivative with respect to $\gamma$ and

$$
\frac{\partial q(\gamma, \theta)}{\partial \gamma}>0, \frac{\partial^{2} q(\gamma, \theta)}{\partial \gamma^{2}}<0
$$

- $\quad$ IBs may use a number of methods to provide extra services to investee firms and thus help them increase profits. The services include technical transfer, supervision and consultation, and help financial administration. IBs provide these services to increase the firms' profits. Let $a \geq 0$ represent IB participation. This paper attempts to find out whether due to IB participation, $a$, help the firms to increase their profits;

- Investors tend to support entrepreneurs to minimize agency-related issues between investors and entrepreneurs, and thus prevent entrepreneurs from putting their personal interests first and thereby hurting the firms' interests. As far as income compensation is concerned, entrepreneurs are entitled to a fixed amount of remuneration and variable compensation - bonuses and dividends. The amount of variable compensation is determined in accordance with the profits of the investee firms. It is assumed that the entrepreneur's compensation increases as the firms' profit increases. Let $p \in(0,1)$ represent the proportion of profits shared with the entrepreneurs. An IB helps firms to increase profits through participation and, therefore, the firms' profits are determined by the IB's participation. Hence $(1+a) q(\gamma, \theta)$ represents the profits of firms with IB's participation and also $(1+a) q(\gamma, \theta)$ represents the entrepreneur's variable compensation. Let $f \geq 0$ represent the fixed amount of compensation for entrepreneurs. Then the incentive plan for entrepreneurs is represented by the linear structure as follows:

$$
\begin{gathered}
f+(1+a) q(\gamma, \theta) p . \text { Set and rearrange } \\
C_{e}:=f+(1+a) q(\gamma, \theta) p \\
U\left(C_{e}, \gamma\right)=M\left(C_{e}\right)-K(\gamma)
\end{gathered}
$$


Delpachitra: Is Islamic banking capable of meeting corporate social responsibi

and

$C_{v}=(1+a) q(\gamma, \theta)(1-p)-f$

Then $C_{e}$ represents the entrepreneurs' compensation and $C_{v}$ represents the compensation for the Islamic investors.

As the IBs increase their participation, Islamic investors are more likely to launch a reward system to encourage entrepreneurs to improve the operating performance of the firms, thereby solving the agency-related issues between Islamic investors and entrepreneurs and improving the firms' operating performance; thus creating a win-win situation. If the whole process is Sharitah compliant, Islamic investors are likely to share a higher percentage of profits with entrepreneurs as IBs increase their participation in investee firms;

- Consistent with Holmstrom (1979), this paper assumes that the Von Neumann-Morgenstern utility function (abbreviated as VN-M utility function) represents the utility functions for the principles and agents. Let

$$
V\left(C_{v}\right)=V[(1+a) q(\gamma, \theta)(1-p)-f]
$$

be the utility function for Islamic investors and

$$
\begin{aligned}
U\left(C_{e}, \gamma\right) & =M\left(C_{e}\right)-K(\gamma) \\
& =M[f+(1+a) q(\gamma, \theta) p]-K(\gamma)
\end{aligned}
$$

be the utility function for entrepreneurs, where $M\left(C_{e}\right)$ represents the utility of the profits earned by the entrepreneurs from the firms and $K(\gamma)$ represents the negative utility created by the investee firms' technologies for the entrepreneurs. $V, M$ and $K$ are assumed to be continuously differentiable up to their second-order derivatives. In addition, it is assumed that Islamic investors and entrepreneurs are risk averse and their utility increases and marginal utility decreases as their wealth increases, that is,

$$
V^{\prime}\left(C_{v}\right)=\frac{d V\left(C_{v}\right)}{d C_{v}}>0, V^{\prime \prime}\left(C_{v}\right)=\frac{d^{2} V\left(C_{v}\right)}{d C_{v}^{2}}<0
$$

and

$$
M^{\prime}\left(C_{e}\right)=\frac{d M\left(C_{e}\right)}{d C_{e}}>0, M^{\prime \prime}\left(C_{e}\right)=\frac{d^{2} M\left(C_{e}\right)}{d C_{e}^{2}}<0
$$

Function $K(\gamma)$ represents the negative utility created by the investee firms' technologies for the entrepreneurs. The negative effect is assumed to increase as the investee firms enhance their operational capabilities for the entrepreneurs and the marginal negative utility increases as the investee firms enhance their operational capabilities, i.e., 


$$
K^{\prime}(\gamma)=\frac{d K(\gamma)}{d \gamma}>0, K^{\prime \prime}(\gamma)=\frac{d^{2} K(\gamma)}{d \gamma^{2}}>0
$$

\subsection{Model Inference and Proposition}

The contractual behaviors between Islamic investors and entrepreneurs are analyzed in the context of the assumptions made at the beginning. Both parties understand that the other intends to maximize utility rationally. Therefore, the contractual behavior is expressed in the optimization and implications equation as follows:

$$
{ }_{a, p, f}^{\operatorname{Max}} \mathbf{E} \theta\left[V\left(C_{v}\right)\right]
$$

subject to

$$
\mathbf{E}_{\ominus}\left[U\left(C_{e}, \gamma\right)\right] \geq \bar{u}
$$

and

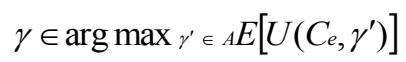

An optimum strategy or optimal solution of the optimization problem (8)-(10) is assumed to exist for the investor.

According to Equation (8), Islamic investors select the most suitable contracts to maximize their expected utility. Equation (9) represents the entrepreneurs' considerations regarding opportunity costs, where $\bar{u}$ represents the reserved utility level, which assumes entrepreneurs' expected utility to stay above a certain level. In reality, $\bar{u}$ is determined in accordance with the market situation. If the utility created by the agency contract is lower than the utility determined by the market, entrepreneurs are unlikely to accept the agency contract.

Equation (10) relates to the decisions that maximize the entrepreneurs' expected utility under the incentive plan $C_{e}=f+(1+a) q(\gamma, \theta)$. Islamic investors are not familiar with the operational capabilities of the investment objects when they enter into a contract. The asymmetry of the information between Islamic investors and entrepreneurs is characterized by the dependence on $\gamma$ in their utilities. Entrepreneurs are likely to initiate the decisions related to the operational advancement based upon their personal interest and religious beliefs, and thus maximize their expected utility.

The necessary condition of the constraint (10) is given by its first order condition with respect to $\gamma$. Taking the utility function for entrepreneurs $U\left(C_{e}, \gamma\right)$, we differentiate this with respect to $\gamma$ to obtain the necessarycondition

$$
\frac{\partial E\left[U\left(C_{e}, \gamma\right)\right]}{\partial \gamma}=0
$$


Taking the expression for entrepreneurs' compensation given by $C_{e}=f+(1+a) q(\gamma, \theta)$ and substituting this in the utility function for entrepreneurs $U\left(C_{e}, \gamma\right)=M\left(C_{e}\right)-K(\gamma)$, we have from (11) that

$$
\frac{\partial E[M(f+(1+a) q(\gamma, \theta) p)-K(\gamma)]}{\partial \gamma}=0
$$

Assume the probability distribution of $\theta$ is continuous. It then follows from Leibnitz's rule and (4.1.12) that

$$
E\left\lceil\frac{d M\left(C_{e}\right)}{d C_{e}}(1+a) p \frac{\partial q}{\partial \gamma}\right\rceil-K^{\prime}(\gamma)=0
$$

To simplify the discussion, assume necessary conditions for the implicit function theorem to hold so that $\gamma$ can be solved implicitly from equation (1.13) in terms of other variables. Therefore $\chi$ an be determined as a function of $(a, p, f)$, that is, $\gamma \quad \gamma=\gamma(a, p, f)$.

To obtain the necessary conditions for the optimization, the Lagrangian multiplier is introduced (based on the necessary condition (13) of (10) and (8)-(9)),

$$
\begin{aligned}
& \left.L(a, p, f ; \gamma, \lambda, \mu):=\mathbf{E}_{\theta}\left[V\left(C_{v}\right)\right]+\lambda \mid \bar{h}-\mathbf{E}_{\theta}\left[U\left(C_{e}, \gamma\right)\right]\right] \\
& +\mu\left(E\left[M^{\prime}(C e)(1+a) p \frac{\partial q}{\partial \gamma}\right\rfloor-K^{\prime}(\gamma)\right)
\end{aligned}
$$

where $\lambda$ and $\mu$ are the corresponding Lagrangian multipliers. Under the assumption of the existence of the optimal solution of the optimization problem, the Kuhn-Tucker Theorem (see pp. 740-741 in Chapter 19 in Taha, 1992) is used to obtain the following necessary conditions for the optimal solution $\left(a^{*}, p^{*}, f^{*} ; \gamma^{*}\right)^{1}$

$$
\begin{aligned}
& \frac{\partial L}{\partial a}=0, \frac{\partial L}{\partial p}=0, \quad \frac{\partial L}{\partial f}=0, \\
& \mathbf{E}_{\theta}\left[U\left(C_{e}, \gamma\right)\right] \geq \bar{h}, \quad \lambda \geq 0, \quad \lambda\left(\mathbf{E}_{\theta}\left[U\left(C_{e}, \gamma\right)\right]-\bar{h}\right)=0 \\
& E\left[\frac{d M\left(C_{e}\right)}{d C_{e}}(1+a) p \frac{\partial q}{\partial \gamma}\right]-K^{\prime}(\gamma)=0
\end{aligned}
$$

Therefore, if $\left(a^{*}, p^{*}, f^{*}, \gamma^{*}\right)$ is an optimal solution of the optimization problem, it should satisfy the necessary conditions (15)-(17). Based on these assumptions, $\gamma^{*}=\gamma^{*}(a, p, f)$ solves the equation (17). After substituting $\gamma^{*}=\gamma(a, p, f)$ into (1.15) and (1.16), the constrained optimization problem is treated as finding a solution in variable $(a, p, f)$. The optimal solution is then substituted, say $\left(a^{*}, p^{*}, f^{*}\right)$, back to $\gamma^{*}$ to obtain $\gamma^{*}=\gamma^{*}\left(a^{*}, p^{*}, f^{*}\right)$.

There is no condition on $\mu$ after equation (1.17) since the constraint (1.13) is an equality, unlike the inequality constrain in equation (1.16) 
International Journal of Banking and Finance, Vol. 10, Iss. 2 [2013], Art. 6 60

The following discussion examines how the profit-sharing ratio designed by an IB for entrepreneurs and the investee firms' operational capabilities are related. Intuitively, the profit-sharing ratio $p$ designed by the IB for the entrepreneurs would encourage the entrepreneurs to improve the investee firm's operational capabilities $\gamma$. In other words, the entrepreneurs are likely to increase the investee's operational capabilities $\gamma$ as more profits are allocated to the entrepreneurs. Mathematically, this suggests that

$$
\frac{\partial \gamma}{\partial p}>0
$$

The sufficient conditions under which (1.18) holds are now derived.

Denote

$$
W(a, p, f ; \gamma):=\mathbf{E}\left[\frac{d M\left(C_{e}\right)}{d C_{e}}(1+a) p \frac{\partial q}{\partial \gamma}\right]-K^{\prime}(\gamma)
$$

It then follows from the necessary condition (17) that

$$
W(a, p, f ; \gamma)=0
$$

Equation (20) is differentiated with respect to $\gamma$ to obtain

$$
\frac{\partial W}{\partial p}+\frac{\partial W}{\partial \gamma} \frac{\partial \gamma}{\partial p}=0
$$

Based on the assumption that the utility function $M$ is twice continuously differentiable, Leibnitz's rule is used to obtain from (19) that

$$
\frac{\partial W}{\partial p}=\mathbf{E}\left[\frac{d^{2} M\left(C_{e}\right)}{d C_{e}^{2}} \frac{\partial C_{e}}{\partial p}(1+a) p \frac{\partial q}{\partial \gamma}+\frac{d M\left(C_{e}\right)}{d C_{e}}(1+a) \frac{\partial q}{\partial \gamma}\right]
$$

and

$$
\frac{\partial W}{\partial \gamma}=\mathbf{E}\left[\frac{d^{2} M\left(C_{e}\right)}{d C_{e}^{2}} \frac{\partial C_{e}}{\partial \gamma}(1+a) p \frac{\partial q}{\partial \gamma}+\frac{d M\left(C_{e}\right)}{d C_{e}}(1+a) p \frac{\partial^{2} q}{\partial \gamma^{2}}\right]-K^{\prime \prime}(\gamma)
$$

Note that

$$
\frac{\partial C_{e}}{\partial p}=(1+a) q(\gamma, \theta), \quad \frac{\partial C_{e}}{\partial \lambda}=(1+a) p\left(\frac{\partial q(\gamma, \theta)}{\partial \gamma}\right)
$$

It then follows from (22) and (23) that

$$
\frac{\partial W}{\partial p}=\mathbf{E}\left[\frac{d^{2} M\left(C_{e}\right)}{d C_{e}^{2}}(1+a)^{2} p q(\gamma, \theta) \frac{\partial q}{\partial \gamma}+\frac{d M\left(C_{e}\right)}{d C_{e}}(1+a) \frac{\partial q}{\partial \gamma}\right]
$$


Delpachitra: Is Islamic banking capable of meeting corporate social responsibi

and

$$
\frac{\partial W}{\partial \gamma}=\mathbf{E}\left[\frac{d^{2} M\left(C_{e}\right)}{d C_{e}^{2}}(1+a)^{2} p^{2}\left(\frac{\partial q}{\partial \gamma}\right)^{2}\right]+E\left[\frac{d M\left(C_{e}\right)}{d C_{e}}(1+a) p \frac{\partial^{2} q}{\partial \gamma^{2}}\right]-K^{\prime \prime}(\gamma)
$$

The sign of $\frac{\partial W}{\partial \gamma} \quad$ in (1.25) is now examined. From the assumption that $a \geq 0, p \geq 0, M^{\prime \prime} \leq 0, \frac{\partial^{2} q}{\partial \gamma^{2}}<0$ and, $K^{\prime \prime}>0$ it can be seen from (25) that

$$
\frac{\partial W}{\partial \gamma}<0
$$

Noting that $M^{\prime}>0$, equation (24) can be rewritten as

$$
\frac{\partial W}{\partial p}=\mathbf{E}\left[(1+a) M^{\prime}\left(C_{e}\right)\left(1-\frac{-1(1+a) p q(\gamma, \theta) M^{\prime \prime}\left(C_{e}\right)}{M^{\prime}\left(C_{e}\right)}\right) \frac{\partial q}{\partial \gamma}\right]
$$

Entrepreneurs' compensation includes a fixed amount of remuneration and variable remuneration $(1+a) q(\gamma, \theta) p$. Therefore, $f$ is considered the entrepreneurs' fixed wealth and the variable remuneration $(1+a) q(\gamma, \theta) p$ is considered a risky asset. The entrepreneurs' risks increase as the risk of the risky asset increases. It is assumed that the entrepreneurs avoid risks and the relative risk aversion coefficient of the utility function $M$ of entrepreneurs is smaller than one (see Huang \& Litzenberger (1988) for the definition and related discussion),

$$
C_{e} \frac{-M^{\prime \prime}\left(C_{e}\right)}{M^{\prime}\left(C_{e}\right)}<1
$$

Note that $M^{\prime}>0, M^{\prime \prime}<0, f \geq 0$ and

$(1+a) p q(\gamma, \theta) \leq f+(1+a) p q(\gamma, \theta)=C_{e}$

Hence

$$
\frac{-(1+a) p q(\gamma, \theta) M^{\prime \prime}\left(C_{e}\right)}{M^{\prime}\left(C_{e}\right)} \leq \frac{-C_{e} M^{\prime \prime}\left(C_{e}\right)}{M^{\prime}\left(C_{e}\right)}<1
$$

This implies that

$$
1-\frac{-1(1+a) p q(\gamma, \theta) M^{\prime \prime}\left(C_{e}\right)}{M^{\prime}\left(C_{e}\right)}>0
$$


International Journal of Banking and Finance, Vol. 10, Iss. 2 [2013], Art. 6 62

Note that $M^{\prime}>0$ and $1+a+>0$, we have from (1.29) that

$$
(1+a) M^{\prime}\left(C_{e}\right)\left(1-\frac{-1(1+a) p q(\gamma, \theta) M^{\prime \prime}\left(C_{e}\right)}{M^{\prime}\left(C_{e}\right)}\right)>0
$$

Following from the assumption $\frac{\partial q}{\partial \gamma}>0$, we obtain from (27) and (30) that

$$
\frac{\partial W}{\partial p}=\mathbf{E}\left[(1+a) M^{\prime}\left(C_{e}\right)\left(1-\frac{-1(1+a) p q(\gamma, \theta) M^{\prime \prime}\left(C_{e}\right)}{M^{\prime}\left(C_{e}\right)}\right) \frac{\partial q}{\partial \gamma}\right]
$$

This, together with (26) and (21), leads to (18). It is, therefore shown that (18) holds under condition (28). By summarizing the analysis, Proposition 1 is obtained.

Proposition 1: Assume

$$
\frac{-C_{e} M^{\prime \prime}\left(C_{e}\right)}{M^{\prime}\left(C_{e}\right)}<1
$$

Then

$$
\frac{\partial \gamma}{\partial p}>0
$$

In other words, if the relative risk aversion coefficient of the utility function $M$ of the entrepreneurs is strictly less than one, then as the IB distributes a higher percentage of profits to entrepreneurs, the investee firms' operational capabilities are improved.

Similarly, the investees' operational capabilities are expected to increase as the IB increases its participation. Mathematically, this corresponds to

$$
\frac{\partial \gamma}{\partial a}>0
$$

Equation (1.32) holds under condition (1.28). Equation (1.20) is differentiated with respect to $a$ to obtain

$$
\frac{\partial W}{\partial a}+\frac{\partial W}{\partial \gamma} \frac{\partial \gamma}{\partial a}=0
$$


Delpachitra: Is Islamic banking capable of meeting corporate social responsibi

Based on the assumption that the utility function $M$ is twice continuously differentiable, Leibnitz's rule is used to obtain from (19) that

$$
\frac{\partial W}{\partial a}=\mathbf{E}\left[\frac{d^{2} M\left(C_{e}\right)}{d C_{e}^{2}} \frac{\partial C_{e}}{\partial a}(1+a) p \frac{\partial q}{\partial \gamma}+\frac{d M\left(C_{e}\right)}{d C_{e}} p \frac{\partial q}{\partial \gamma}\right]
$$

Note that

$$
\frac{\partial C_{e}}{\partial a}=p q(\gamma, \theta)
$$

It then follows from (1.34) that

$$
\begin{aligned}
& \frac{\partial W}{\partial a}=\mathbf{E}\left[M^{\prime}\left(C_{e}\right)(1+a) p^{2} q(\gamma, \theta) \frac{\partial q}{\partial \gamma}+M^{\prime}\left(C_{e}\right) p \frac{\partial q}{\partial \gamma}\right] \\
& =\mathbf{E}\left[M^{\prime}\left(C_{e}\right) p \frac{\partial q}{\partial \gamma}\left(1-\frac{-M^{\prime \prime}\left(C_{e}\right)(1+a) p q(\gamma, \theta)}{M^{\prime}\left(C_{e}\right)}\right)\right]
\end{aligned}
$$

We have shown that $\frac{\partial W}{\partial \gamma}<0$. From the assumption that, $M^{\prime}>0, p>0, \frac{\partial q}{\partial \gamma}>0$, condition (1.28) and equation (1.35), we have $\frac{\partial W}{\partial a}>0$. It then follows from (33) that (32) holds. This leads to Proposition 2.

Proposition 2. Assume

$$
\frac{-C_{e} M^{\prime \prime}\left(C_{e}\right)}{M^{\prime}\left(C_{e}\right)}<1
$$

then,

$$
\frac{\partial q(\gamma, \theta)}{\partial p} \frac{\partial q(\gamma, \theta)}{\partial a}
$$

In other words, if the relative risk aversion coefficient of the utility function $M$ of the entrepreneurs is strictly less than one, then as the IBs increase their participation, the investee firms' operational capabilities are improved. 
International Journal of Banking and Finance, Vol. 10, Iss. 2 [2013], Art. 6

The ultimate purpose of the model is to find out whether the changes in IBs' participation and the changes of the entrepreneurs' profit-sharing ratio affect the investee firms' operating performance. In this model, profit $q(\gamma, \theta)$ represents the investee firms' operating performance. Therefore, the following are investigated:

$\frac{\partial q(\gamma, \theta)}{\partial p}$ and $\frac{\partial q(\gamma, \theta)}{\partial a}$.

It follows from $q=q(\gamma, \theta)$ and that $\gamma=\gamma(a, p, f)$

$\frac{\partial q(\gamma, \theta)}{\partial p}=\frac{\partial q(\gamma, \theta)}{\partial \gamma} \frac{\partial \gamma}{\partial p}, \quad \frac{\partial q(\gamma, \theta)}{\partial a}=\frac{\partial q(\gamma, \theta)}{\partial \gamma} \frac{\partial \gamma}{\partial a}$

It then follows from $\frac{\partial q(\gamma, \theta)}{\partial \gamma}>0,(18)$ and (32) that under the same assumption $\frac{\partial q(\gamma, \theta)}{\partial p}>0, \quad \frac{\partial q(\gamma, \theta)}{\partial a}>0$

This leads to the following Proposition 3.

Proposition 3. Assume

$\frac{-C_{e} M^{\prime \prime}\left(C_{e}\right)}{M^{\prime}\left(C_{e}\right)}<1$

then

$\frac{\partial q(\gamma, \theta)}{\partial p}>0, \quad \frac{\partial q(\gamma, \theta)}{\partial a}>0$

In other words, if the relative risk aversion coefficient of the utility function $M$ of the entrepreneurs is strictly less than one, then the final propositions are:

1 : As IBs increase their participation, the investee firms' operating performance is improved;

2 : As IBs share a higher percentage of profits with entrepreneurs, the investee firms' operating performance is improved.

\section{Summary and Conclusions}

Information asymmetry is a fundamental problem in agency-related issues between the IB and entrepreneurs. IBs provide funds, extra services and 
supervisory measures to the investee firms to overcome both agency-related and religious-compliance-related issues. IBs also design the incentive plan to inspire the agents, thereby improving the investee firms' operating performance through their participation and incentive system.

Typically, agency theories stress the value of information and advocate that the incentive system encourages the agents to increase the firms' profits. Conventional agency theory stresses the value of information and, as a result, overlooks the importance of technology, learning for the firms with respect to creating value, and more importantly the role of religion. As stated in Proposition 1 , the investee firms' operating performance is improved as IBs increase their participation. The IBs' supervision mechanism reduces the information asymmetry and therefore, affects the investee firms' operating performance positively. The influence imposed by the incentive plan on the investee firms' operating performance is also examined.

Proposition 2 states that the investee firms' operating performance is improved as the IB shares a higher percentage of profits to the entrepreneurs. Incentive plans launched by IBs affect investee firms' operating performance positively. Over all, if the objective of Islamic banking is to promote the welfare of the society then, by carrying out financial services as designed by IB principles, IBs will be able to ensure that their activities are socially responsible.

Author Information: The author wishes to record his gratitude to the following for their research assistance on this study: Tieh Shang Jin and Jamila Alaktif. Sarath Delpachitra is a professor in the Flinders Business School, Flinders University, Australia. He may be contacted at: Email: sarath.delpachitra@ flinders.edu.au; Phone: 61882013893

\section{References}

Abdallah, A., \& Delpachitra, S. B. (2008). Is Islamic banking a successful alternative to conventional banking? A comparison of tow banking. In Proceedings on the Symposium of Islamic Banking and Finance: Global Perspective on Ethics and Financial Practices, 20 December 2008. Melbourne: National Centre of Excellence for Islamic Studies, University of Melbourne.

Acquier, A. \& Aggeri, F. (2008). Une généalogie de la pensée managériale sur la RSE. Revue Française de Gestion, 34(180), pp. 131-157.

Amit, R., Glosten, L., \& Muller, E. (1990). Does venture capital foster the most promising entrepreneurial firms? California Management Review, 32, pp.102-111.

Anwar, M. (2003). Islamicity of banking and modes of Islamic banking. Arab Law Quarterly, 18(1), pp. 62-80.

Archer, S., \& Abdel Karim, R. A. (2002). Agency theory, corporate governance and the accounting regulation of Islamic banks. Research in Accounting Regulation, 1(1), pp. 97-114. 
Bowen, H. (1953). Social responsibilities of the businessman. New York: Harper and Brothers.

Caroll, A. (1979). A three-dimensional conceptual model of corporate social performance. Academy of Management Review, 4(4), pp. 497-505.

Dhumale, R \& Sapcanin, A. (2003). An application of Islamic banking principles to microfinance. Technical note. A study by the Regional Bureau for Arab States, UNDP, in cooperation with the Middle East and North Africa Region, World Bank.

El-Hawary, D., Grais, W., \& Iqbal, Z. (2004). Regulating Islamic financial institutions: The nature of the regulated. World Bank Policy Research Working Paper, No. 3227, March.

Guyot, A. (2009). Le coût de l'investissement islamique : L'application des critères Dow Jones Islamic au marché d'actions Euronext Paris. EuroMediterranean Economics Finance Review, Special Issue for IFC 5, 4(3), Third Quarter, pp. 127-140.

Hasan, Z. (2002). Murābalah as a mode of finance in Islamic banking: Theory, practices and problems. The Middle East Business and Economic Review, 14(2), pp. 41-53.

Holmstrom, B. (1979). Moral hazard and observability. Bell Journal of Economics, 10, pp. 74-91.

Huang, C., \& Litzenberger, R. H. (1988). Foundations for financial economics. Upper Saddle River, NJ: Prentice Hall.

Lewis, M. \& Algaoud, L. M. (2001). Islamic banking. Cheltenham, UK: Edward Elgar.

Lin, S. H. (2004). Research on the uncertainty of venture capital funds performance. Working Paper, National Taiwan University.

Sairally, S. (2007). Evaluating the 'social responsibility' of Islamic finance: Learning from the experience of socially responsible investment funds. In Munawar Iqbal, Salman Syed Ali and Dadang Muljawan, Advances in Islamic Economics and Finance Vol. 1. Jeddah: Islamic Research and Training Institute.

Sarker, A. M. (1999). Islamic business contracts, agency problem and the theory of Islamic firm. International Journal of Islamic Financial Services, 1(2), pp. 15-49.

Shleifer A. \& Vishny, R. W. (1997). A survey of corporate governance. The Journal of Finance, 52, pp. 737-783.

Taha, H. A. (1992). Operation research: An introduction. New York: Maxwell Macmillan.

Winant, P. (2008). La finance éthique. Regards croisés sur l'économie, 1(3), pp. 84-85. 